\title{
BIMBINGAN KETERAMPILAN ANAK TUNAGRAHITA
}

\author{
Oleh: \\ Adam Bagus Primohardjo, Santoso Tri Raharjo, \& Arie Surya Gutama
}

Email:

primohardjo@yahoo.com

\begin{abstract}
ABSTRAK Tunagrahita atau terbelakang mental merupakan kondisi di mana perkembangan kecerdasannya mengalami hambatan sehingga tidak mencapai tahap perkembangan yang optimal. Bimbingan keterampilan anak tunagrahita yang dilakukan oleh panti sosial bina grahita merupakan upaya pemerintah dalam mengatasi masalah kesejahteraan sosial. Dengan adanya bimbingan keterampilan bagi anak tunagrahita diharapkan mampu berfungsi secara sosial. Soetarso dalam Pengantar Kesejahteraan Sosial mengemukakan, social grup work atau bimbingan sosial kelompok adalah suatu metode untuk bekerja dengan, dan menghadapi orang-orang di dalam suatu kelompok, guna peningkatan kemampuan untuk melaksanakan fungsi sosial; serta guna pencapaian tujuantujuan yang secara sosial dianggap baik. Peneliti menggunakan metode penelitian kualitatif karena ingin mendalami pelaksanaan bimbingan keterampilan bagi anak tunagrahita di suatu panti sosial bina grahita dan hasil penelitian berupa rincian data yang lebih kompleks tentang fenomena yang sulit diungkapkan oleh metode kuantitatif dan tidak memerlukan pengolahan data secara statistika. Hasil dari penelitian kualitatif yang dibutuhkan peneliti adalah berupa informasi yang mendalam mengenai suatu kondisi pada objek tersebut.
\end{abstract}

ABSTRACT Tunagrahita or mentally retarded is a condition in which the development of intelligence experience barriers so as not to reach the optimum stage of development. Counseling skills of children with intellectual challenges undertaken by social institutions are coached mentally government efforts to address the problem of social welfare. With the guidance of skills for children with intellectual challenges expected to be able to function socially. Soetarso in Introduction to Social Welfare points out, social group or social assistance group work is a method to work with, and confront people in a group, in order to improve the ability to perform a social function; as well as to the achievement of objectives that are socially considered good. Researchers used qualitative research methods because they want to explore the implementation of skills counseling for children with intellectual challenges in a social institution building mentally and research results in the form of complex data more details about the phenomenon that is difficult to express by quantitative methods and does not require statistical data processing. The results of qualitative research is needed researcher is in the form of in-depth information about a condition on those objects.

\section{PENDAHULUAN}

Penyandang tuna grahita termasuk dalam kelompok penyandang masalah kesejahteraan sosial (PKMS). Hal ini karena dalam proses interaksi antara penyandang tuna gragita dengan masyarakat di lingkungannya sering berjalan kurang baik. Penyandang tuna grahita sering mengalami diskriminasi dan 
ketersisihan. Kondisi tersebut mendorong mereka menjadi individu yang tidak berdaya dalam menjalani aktivitas sosialnya dan mengalami kesulitan dalam memperjuangkan kesejahteraan sosialnya. Melalui UndangUndang No. 4 tahun 1997 tentang Penyandang Disabilitas dan Peraturan Pemerintah Republik Indonesia no. 43 tahun 1998 tentang Upaya Kesejahteraan Penyandang Disabilitas, Pemerintah Republik Indonesia telah menjamin secara legal formal segala persamaan hak dan kedudukan para penyandang disabilitas dengan warga negara Indonesia yang lain. Kesamaan hak dan kedudukan itu diantaranya ialah kesamaan dalam memperoleh pendidikan, pekerjaan dan penghidupan yang layak, berperan dan menikmati hasil-hasil pembangunan, aksesbilitas dalam mencapai kemandirian, rehabilitasi, bantuan sosial, dan pemeliharaan taraf kesejahteraan sosial, serta menumbuh kembangkan bakat, kemampuan dan kehidupan sosialnya (Bapemas, 2011: 1). Salah satu bentuk realisasi dari undang-undang dan peraturan pemerintah tersebut yaitu dengan dengan disediakannya panti rehabilitasi sosial bina grahita.

Pemerintah Provinsi DKI Jakarta melalui Dinas Sosial melakukan beragam program berbasis masyarakat. Hal ini dilakukan dengan meningkatkan harkat, martabat, serta kualitas hidup manusia. Upaya lain yaitu dengan mencegah dan mengendalikan serta mengatasi masalah sosial, meningkatkan ketahanan dan pemberdayaan sosial masyarakat, meningkatkan pelayanan rehabilitasi sosial, mengembangkan system perlindungan dan jaminan sosial serta mengembangkan system dan sasaran serta Unit Kesejahteraan Sosial.

Panti sosial Bina Grahita yang dikelola Dinas Sosial merupakan implementasi nyata dari hal diatas. Panti Sosial Bina Grahita menyelenggarakan rehabilitasi sosial bagi penyandang disabilitas mental / Tuna Grahita. Layanan yang diberikan di Panti Sosial Bina Grahita ini meliputi pendekatan awal melalui orientasi indentifikasi, motivasi dan seleksi, melakukan penerimaan melalui registrasi, assessment dan penempatan, memberikan pelayanan dan perawatan meliputi permakanan, peningkatan gizi, konseling dan pemantauan perkembangan psikologi, perawatan kesehatan, kebersihan dan terapi serta bimbingan dan keterampilan, melakukan penyaluran kembali kekeluarga dan rujukan ke instansi lain.

Sejatinya anak tuna grahita harus memiliki keterampilan seperti halnya manusia pada umumnya. Walaupun memiliki keterbatasan, anak tuna grahita bukan tidak mungkin memiliki keterampilan yang setara dengan manusia normal. Dengan adanya bimbingan keterampilan yang dilakukan oleh Panti Sosial Bina Grahita kepada anak tuna grahita, diharapkan anak tuna grahita mampu berfungsi secara sosial baik untuk dirinya sendiri ataupun untuk lingkungan sekitarnya agar dapat lebih meningkatkan fungsionalitas mereka sehingga dapat hidup secara produktif.

\section{Metode Penulisan}

Peneliti menggunakan metode penelitian deskriptif karena peneliti hanya meneliti dari satu variabel yang merupakan suatu kondisi pada objek tersebut. Pada penelitian ini, Peneliti melakukan penelitian pada variabel tersebut tanpa adanya perbandingan dengan variabel lain. Penelitian ini bermaksud mendeskripsikan secara abstrak, dan mencari makna dari suatu peristiwa dengan melakukan observasi dan studi literatur terhadap instansi terkait. Hal ini dilakukan untuk memperoleh keadaan panti. Selain itu Peneliti pun melakukan kajian pustaka dan pengolahan data.

\section{TELAAH PUSTAKA}

\section{Anak Tunagrahita}

Tunagrahita adalah istilah yang digunakan untuk menyebut anak yang mempunyai kemampuan intelektual di bawah rata-rata. Dalam kepustakaan Bahasa asing digunakan istilah-istilah mental retardation, mentally retarded, mental deficiency, mental defective, dan lain-lain. 
Istilah tersebut sesungguhnya memiliki arti yang sama yang menjelaskan kondisi anak yang kecerdasannya jauh di bawah rata-rata dan ditandai oleh keterbatasan intelegensi dan ketidakcakapan dalam interaksi sosial. Anak tunagrahita atau dikenal juga dengan istilah terbelakang mental karena keterbatasan kecerdasannya mengakibatkan dirinya sukar untuk mengikuti program pendidikan di sekolah biasa secara klasikal, oleh karena itu anak terbelakang mental membutuhkan layanan pendidikan secara khsus yakni disesuaikan dengan kemampuan anak tersebut.

\section{Karakteristik anak tunagrahita}

Ada beberapa karakteristik umum tunagrahita yang dapat kita pelajari, yaitu:

\section{$\underline{\text { Keterbatasan Interligensi }}$}

Inteligensi merupakan fungsi yang kompleks yang dapat diartikan sebagai kemampuan untuk mempelajari informasi dan keterampilan-keterampilan menyesuaikan diri dengan masalah-masalah dengan situasisituasi kehidupan baru, belajar dari pengelaman masa lalu, berpikir absktrak, kreatif, dan dapat menilai secara kritis, menghindari kesalahan-kesalahan. Mengatasi kesulitan-kesulitan, dan kemampuan untuk merencanakan masa depan.

\section{Keterbatasan Sosial}

Disamping memiliki keterbatasan inteligensi, anak tunagrahita juga memiliki kesulitan dalam mengurus diri sendiri dalam masyarakat, oleh karena itu mereka memerlukan bantuan.

\section{Keterbatasan Fungsi-fungsi Mental lainya}

Anak tunagrahita memerlukan waktu lebih lama untuk menyelesaikan reaksi pada situasi yang baru dikenalnya. Mereka mempelihatkan reaksi terbaiknya bila mengikuti hal-hal yang rutin dan secara konsisten dialaminya dari hari ke hari. Anak tunagrahita tidak dapat menghadapi sesuatu kegiatan atau tugas dalam jangka waktu yang lama.
Anak tunagrahita memiliki keterbatasan dalam penguasaan bahasa. Mereka bukannya mengalami kerusakan artikulasi, akan tetapi pusat pengolahan yang kurang berfungsi sebagaimana mestinya. Karena alasan itu mereka membutuhkan kata-kata kongkret yang sering didengarnya.

Selain itu, anak tunagrahita kurang mampu untuk mempertimbangkan sesuatu, membedakan antara yang baik dan yang buruk, dan membedakan yang benar dan yang salah. Ini semua karena kemampuannya terbatas sehingga anak tunagrahita tidak dapat membayangkan terlebih dahulu konsekuensi dari suatu perbuatan.

Perkembangan anak tunagrahita

Perkembangan Fisik

Fungsi-fungsi perkembangan anak tunagrahita itu ada yang tertinggal jauh oleh anak normal. Ada pula yang sama atau hampir menyamai anak normal. Di antara fungsi-funsi yang menyamai atau hampir menyamai anak normal ialah fungsi perkembangan jasmani dan motorik.

Perkembangan jasmani dan motorik anak tunagrahita tidak secepat perkembangan anak normal sebagaimana banyak ditulis orang. Hasil penelitian menunjukan bahwa tingkat kesegaran jasmani anak terbelakang mental atau tunatunagrahita yang memiliki MA 2 tahun sampai 12 tahun ada dalam kategori kurang sekali. Sedang anak normal pada umur yang sama ada dalam kategiru kurang (Umardjani Martasuta, 1984). Dengan demikian tingkat kesegaran jasmani anak tunagrahita setingkat lebih rendah dibandingkan dengan anak normal pada umur yang sama.

\section{Perkembangan Kognitif}

Berkenaan dengan memori, anak tunagrahita berbeda dengan anak normal pada short term memory. Anak tunagrahita tampaknya tidak berbeda dengan anak normal dalam long term memory, daya ingatnya sama dengan anak normal. Akan tetapi bukti-bukti menunjukan anak tunagrahita berbeda dengan anak normal 
dalam hal mengingat yang segera (immediate memory).

\section{Perkembangan Bahasa}

Anak tunagrahita pada umunya tidak bisa menggunakan kalimat majemuk, dalam percakapan sehari-hari banyak yang menggunakan kalimat tunggal. Selain itu anak tunagrahita mengalami kelambatan dalam perkembangan bicara (expressive auditory language).

Dalam perkembangan morfologi, anak normal menguasai peningkatan sejumlah morferm sejalan dengan perkembangan umur, demikaian juga anak tunagrahita.

\section{Pelayanan Sosial}

Dalam kehidupan sehari-hari kita sering mendengar yang disebut pelayanan, baik itu pelayanan di rumah sakit, sekolah, rumah ibadah, bahkan di tempat-tempat perbelanjaan sekalipun. Menurut Kamus Besar Bahasa Indonesi (KBBI 2001 : 646), pengertian pelayanan adalah 1. Perihal atau cara melayani 2.usaha melayani kebutuhan orang lain dengan mengharapkan imbalan (uang atau jasa) 3 . Kemudahan yang diberikan sehubungan dengan barang dan jasa. Dari pengertian tersebut kita dapat menarik kesimpulan bahwa pelayanan itu merupakan suatu kegiatan yang diberikan seseorang atau lembaga untuk memenuhi kebutuhan orang lain.

Pelayanan sosial merupakan implementasi perwujudan dari konsep-konsep kesejahteraan sosial dalam usaha memberikan bantuan kepada individu, keluarga, kelompok, dan masyarakat. Pelayanan sosial biasanya dilakukan oleh organisasi pemerintah maupun non-pemerintah. Pelayanan sosial bertujuan untuk meningkatkan kemampuan orang dalam memanfaatkan sumber-sumber yang tersedia. Menurut katalogus Departemen Sosial pelayanan sosial adalah suatu kegiatan yang dilakukan secara profesioanl untuk membantu memecahkan permasalahan sosial yang dialami baik perseorangan, kelompok maupun masyarakat dengan menggunakan pendekatan praktik pekerjaan sosial.

Pelayanan sosial meliputi kegiatan-kegiatan atau intervensi-intervensi terhadap kasus yang muncul dan dilaksanaan secara individu, kelompok dan masyarakat serta memiliki tujuan untuk membantu individu, kelompok, dan lingkungan sosial dalam upaya mencapai penyesuaian dan keberfungsian yang baik dalam segala bidang kehidupan di masyarakat, yang terkandung dalam pelayanan dapat dikatakan adanya kegiatan-kegiatan yang memberikan jasa kepada klien dan membantu mewujudkan tujuan-tujuan mereka. Pelayanan sosial itu sendiri merupakan suatu bentuk aktivitas yang bertujuan untuk membantu individu, kelompok, ataupun kesatuan masyarakat agar mereka mampu memenuhi kebutuhan-kebutuhannya, yang pada akhirnya mereka diharapkan dapat memecahkan permasalahan yang ada melalui tindakantindakan kerjasama ataupun melalui pemanfaatan sumber-sumber yang ada di masyarakat untuk memperbaiki kondisi kehidupannya.

\section{Bimbingan keterampilan}

Bimbingan keterampilan anak tunagrahita yang dilakukan oleh panti sosial bina grahita merupakan upaya pemerintah dalam mengatasi masalah kesejahteraan sosial. Dengan adanya bimbingan keterampilan bagi anak tunagrahita diharapkan mampu berfungsi secara sosial. Soetarso dalam Pengantar Kesejahteraan Sosial mengemukakan, social grup work atau bimbingan sosial kelompok adalah suatu metode untuk bekerja dengan, dan menghadapi orang-orang di dalam suatu kelompok, guna peningkatan kemampuan untuk melaksanakan fungsi sosial; serta guna pencapaian tujuantujuan yang secara sosial dianggap baik.

\section{DAFTAR PUSTAKA}

Sugiyono. 2009. Memahami Penelitian Kualitatif. Bandung : Alfabeta. 
Somantri, Sutjihati. 2006. Psikologi Anak Luar Biasa. Bandung: PT Rafika Aditama http://megapolitan.kompas.com/read/2012/10/ $\underline{\text { 03/1129596/Panti.Sosial }}$

Wibawa, Budhi dkk. 2010. Dasar-dasar Pekerjaan Sosial. Bandung: Widya Padjadjaran 